\title{
Erratum to: The Use and Status of Language in Brunei Darussalam
}

Noor Azam Haji-Othman, James McLellan and David Deterding

\section{Erratum to:}

Noor Azam Haji-Othman et al. (eds.), The Use and Status of Language in Brunei Darussalam, https://doi.org/10.1007/978-981-10-0853-5

The original version of the book was inadvertently published without the chapter author affiliation in Chaps. 4, 5, 6, 10 and 13, which have to be included. The erratum book has been updated with the change.

The updated online versions of these chapters can be found at https://doi.org/10.1007/978-981-10-0853-5_4

https://doi.org/10.1007/978-981-10-0853-5_5

https://doi.org/10.1007/978-981-10-0853-5_6

https://doi.org/10.1007/978-981-10-0853-5_10

https://doi.org/10.1007/978-981-10-0853-5_13

https://doi.org/10.1007/978-981-10-0853-5 